\title{
Wybrane aspekty edukacji formalnej i pozaformalnej w kształtowaniu świadomości społeczeństwa w zakresie bezpieczeństwa
}

\section{Selected aspects of formal and non-formal education in shaping society's awareness of security}

\section{Abstract}

Based on theoretical considerations and analyzing practical activities implemented in the area of shaping public awareness of security, the article attempts to characterize educational entities, non-governmental organizations and uniformed services that have the most significant impact on the issues discussed.

The aim of the article is to present the process of transferring knowledge, shaping skills and competences in the area of security through institutional education and the activity of all entities operating in the process of shaping human security.

The article presents a modern and comprehensive approach to the implementation of tasks in the field of education for security, the essence of cooperation between formal and non-formal education and its role in shaping the public awareness of security, taking into account its interdisciplinarity. It was pointed out that the condition for building a strong state security system is the education of an aware society, prepared to react to events with the features of a crisis.

Keywords: education, education for security, safety, uniformed services, non-governmental organizations, social prevention 


\section{Некоторые аспекты формального и неформального образования в формировании сознания общества о безопасности}

\section{Аннотация}

На основе теоретических соображений и анализа практических мероприятий, реализуемых в области формирования общественного сознания о безопасности, в статье делается попытка охарактеризовать образовательные учреждения, неправительственные организации и силовые структуры, оказывающие наиболее существенное влияние на обсуждаемые вопросы.

Цель статьи - представить процесс передачи знаний, формирования навыков и компетенций в области безопасности через институциональное образование и деятельность всех субъектов, участвующих в процессе формирования безопасности человека.

В статье представлен современный и комплексный подход к реализации задач в сфере образования для безопасности, сущность сотрудничества формального и неформального образования и его роль в формировании общественного сознания о безопасности с учетом его междисциплинарности. Было отмечено, что условием построения сильной системы государственной безопасности является воспитание сознательного общества, готового реагировать на события с признаками кризиса.

Ключевые слова: образование, воспитание в целях безопасности, силовые структуры, неправительственные организации, социальная профилактика

\section{Wprowadzenie}

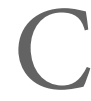
elem artykułu jest ukazanie istoty współdziałania dwóch typów edukacji w systemie kształtowania świadomości społeczeństwa w aspekcie bezpieczeństwa. Istotna jest analiza dostępnej literatury, aktywności realizowanych przez szkoły, organizacje samorządowe i służby mundurowe, a także omówienie wspólnych płaszczyzn kształcenia. Ważne jest odniesienie do tych podmiotów, z którymi współpracują szkoły i jednostki oświatowe.

Aby rozpocząć rozważania dotyczące wybranych aspektów edukacji formalnej i nieformalnej w odniesieniu do kształtowania świadomości społeczeństwa w zakresie bezpieczeństwa, istotne jest przedstawienie i uzgodnienie fundamentalnych pojęć. Zasadniczym terminem powiązanym z poruszaną tematyką jest edukacja, edukacja dla bezpieczeństwa oraz wywieranie wpływu na świadomość społeczeństwa. 
Edukacja to działania, których celem jest wywołanie korzystnych zmian w człowieku. Zmiany te powinny być trwałe, głębokie i wartościowe. Powstają za pośrednictwem procesu uczenia się na płaszczyźnie poznawczej i emocjonalnej. Pojęcie „,edukacja” zawiera w swoim zakresie takie elementy jak: wychowanie, nauczanie oraz kształcenie (Niemierko, 2009, s. 18-20). Według Słownika wyrazów obcych i zwrotów anglojęzycznych Władysława Kopalińskiego edukacja to przede wszystkim wychowanie i kształcenie (etym. - łac. educatio od educare, wychowywać, kształcić) (Kopaliński, 1999, s. 140).Zbigniew Kwieciński uważa, że edukacja to zespół wpływów na jednostkę oraz grupy, które sprzyjają rozwojowi w taki sposób, aby mogły stać się świadomymi i twórczymi członkami społeczeństwa (Kwieciński, 1991, s. 89). Edukacja może mieć wiele celów. Jednym z nich jest zrozumienie idei nauki, jej roli w społeczeństwie, a także możliwości naukowych związanych z gromadzeniem i wykorzystywaniem dorobku różnych dziedzin wiedzy (Harlen, 2010, s. 2-7).

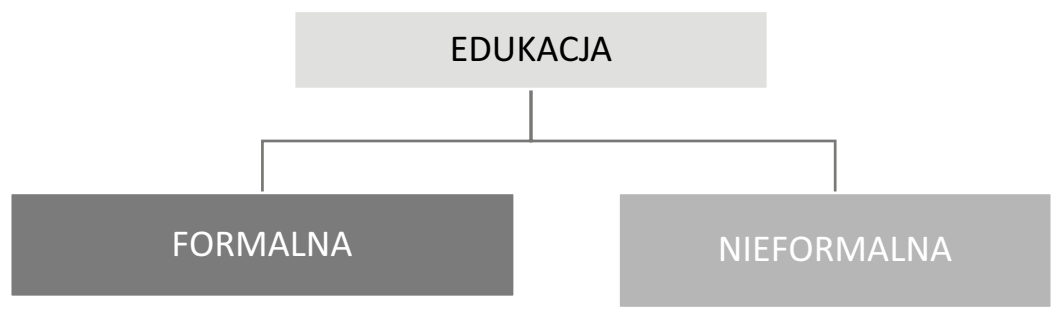

Rys. 1. Podział edukacji: formalna i nieformalna.

Źródło: opracowanie własne.

Edukacja dla bezpieczeństwa może być realizowana za pośrednictwem edukacji formalnej i nieformalnej. Kształcenie formalne jest rozumiane jako system, który opiera się na stałych treściach oraz formach nauki zaprojektowanych od nauczania początkowego do uniwersytetu. System ten obejmuje również wszelkie kursy, programy oferowane przez instytucje oświatowe.

Kształcenie nieformalne, w literaturze nazywane również pozaformalnym oznacza te działania, które mają znamiona kształcenia i wychowania, jednak prowadzone jest poza ustawowym, formalnym systemem szkolnym. Taka forma kształcenia pozwala na osiągnięcie założonych celów kształcenia. Edukacja pozaformalna to wszystkie działania, które mają na celu poszerzanie wiedzy i zdobywanie umiejętności praktycznych. Ta forma obejmuje przede 


\section{Edukacja formalna}

Uznawana przez organy krajowe

Posiada wymogi wiekowe

Forma instytucjonalna

Zakończona certyfikatem z określonymi

kwalifikacjami

Oparta na programach nauczania

Posiada wymogi kwalifikacyjne

Rys. 2. Cechy edukacji formalnej.

Źródło: opracowanie własne na podstawie: Pełech, 2021.

wszystkim aspekty praktyczne i doświadczenie, a od edukacji formalnej różni się głównie metodologią. Swoim zakresem obejmuje nie tylko poszerzanie wiedzy i umiejętności, ale również kształtowanie postaw i wartości (Włodarczyk, 2018, s. 7-14; Zaki, 1988, s. 300-315).

Edukacja dla bezpieczeństwa określana jest jako ogół procesów oświatowo-wychowawczych, które realizowane są głównie przez rodzinę, szkołę,

Edukacja nieformalna

prowadzona poza ustawowym formalnym

systemem szkolnym

ma na celu poszerzanie wiedzy i zdobywanie

umiejętności praktycznych

różni się od formalnej przede wszystkim

metodologią

Rys. 3. Cechy edukacji nieformalnej.

Źródło: opracowanie własne na podstawie: Pełech, 2021. 
środki masowego przekazu, organizacje młodzieżowe, stowarzyszenia oraz przeznaczone do tego instytucje rządowe i samorządowe, których zadaniem jest upowszechnianie wartości, zdobywanie i przekazywanie wiedzy oraz umiejętności niezbędnych do zapewnienia bezpieczeństwa narodowego (Stępień, 1998, 56-62 i s. 218-226).

Edukacja dla bezpieczeństwa pokazuje postęp w kontekście ogólnego doskonalenia się podmiotów, w szczególności formowania się pewności egzystencji. W odniesieniu do zmieniającego się świata bytów kultury i techniki, wiedza i procesy wychowawcze umożliwiają właściwą ocenę tych zmian

\section{EDUKACJA DLA BEZPIECZEŃSTWA}
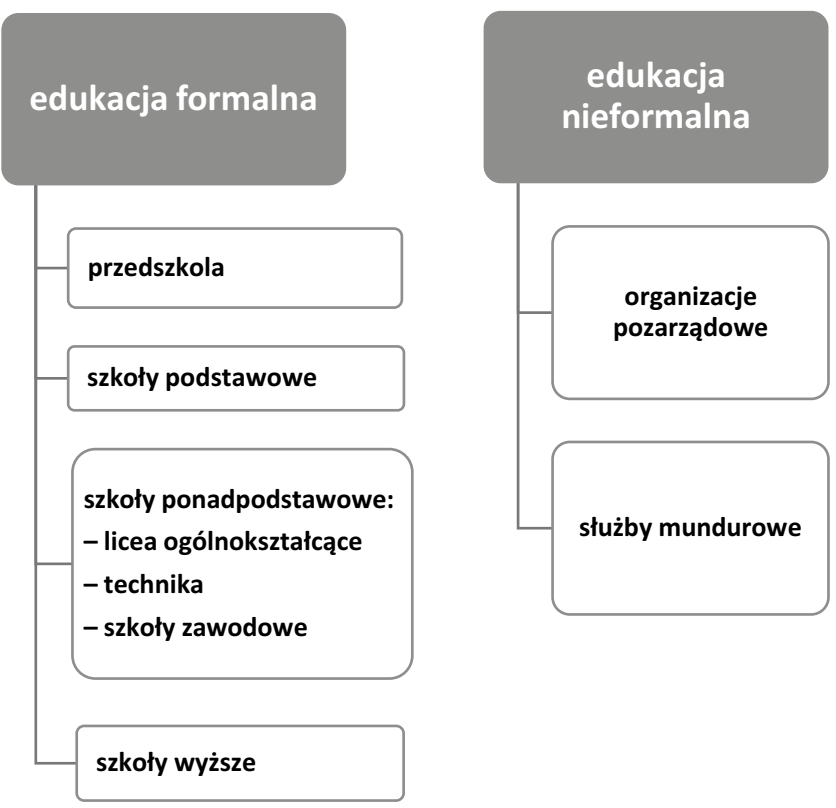

Rys. 4. Podmioty realizujące zadania z zakresu edukacji dla bezpieczeństwa w aspekcie edukacji formalnej i nieformalnej. Cechy edukacji nieformalnej.

Źródło: opracowanie własne. 
i podjęcie właściwych działań, których celem jest eliminowanie i minimalizacja zagrożeń (Elak, 2017, s. 17-41).

Analiza literatury z zakresu edukacji dla bezpieczeństwa wskazuje, iż chociaż liczba publikacji stale się powiększa, to opierać się można głównie na opracowaniach dotyczących prób zdefiniowania pojęcia oraz materiałach konferencyjnych opisujących efekty działań praktycznych. Jednak biorąc pod uwagę fakt, że edukacja dla bezpieczeństwa jest terminem interdyscyplinarnym, można posiłkować się bogatą literaturą z innych dyscyplin nauki, które związane są z procesem edukacji społeczeństwa.

Interdyscyplinarność edukacji dla bezpieczeństwa warunkuje współpracę nie tylko na wielu gruntach nauki, ale również w wymiarze praktycznym. Zgodnie z tym, co pisze Andrzej Pieczywok „Interdyscyplinarność badań naukowych w edukacji dla bezpieczeństwa obejmuje główne dyscypliny naukowe: pedagogikę, filozofię, psychologię, prakseologię, socjologię, antropologię społeczną, politykę społeczną (środowisko pracy i bezpieczeństwo publiczne)" (Pieczywok, 2011, s. 70-77).

Z dotychczasowych rozważań wynika, iż edukację dla bezpieczeństwa możemy realizować dwutorowo: w ramach treści programowych w szkole podstawowej i ponadpodstawowej (w starszych klasach szkoły podstawowej i szkołach średnich jako przedmiot edukacja dla bezpieczeństwa wprowadzony zgodnie z podstawą programową w 2009 r.) lub jako szereg działań i przedsięwzięć profilaktyczno-edukacyjnych, realizowanych przez instytucje państwowe, samorządowe, organizacje pozarządowe czy służby mundurowe (Pieczywok, 2012, s. 10-11).

\section{Edukacja szkolna a edukacja dla bezpieczeństwa}

Przedmiot edukacja dla bezpieczeństwa został wprowadzony 1 września 2009 roku w gimnazjum (od 2018 w szkole podstawowej), a od 1 września 2012 obowiązuje w tym samym wymiarze w szkole ponadpodstawowej. Edukacja dla bezpieczeństwa zastąpiła całkowicie przysposobienie obronne. Obecnie przedmiot ten jest realizowany w ósmej klasie szkoły podstawowej (jedna godzina tygodniowo) oraz w szkołach ponadpodstawowych w drugiej klasie (również w wymiarze jednej godziny tygodniowo). Jednak elementy 
związane z propagowaniem bezpiecznych zachowań i postaw realizowane są w treściach programowych już na etapie edukacji przedszkolnej.

Tematyka poruszana w ramach edukacji formalnej w szkołach jest bardzo szeroka, zgodnie z podstawą programową ustaloną przez Ministerstwo Edukacji Narodowej dotyczy następujących zagadnień: bezpieczeństwo państwa, przygotowanie do działań ratowniczych w sytuacjach nadzwyczajnych zagrożeń, wypadków masowych i katastrof, podstawy pierwszej pomocy, edukacja zdrowotna, zachowania prozdrowotne. Wybór treści uwzględnia dotychczasowy poziom wiedzy uczniów, posiadane zaplecze dydaktyczne, ale również możliwość włączenia w proces dydaktyczny dostępne podmioty zewnętrzne (Lesiński, 2019, s. 4-9).

30 stycznia 2018 r. Minister Edukacji Narodowej Anna Zalewska podpisała rozporządzenie w sprawie nowej podstawy programowej kształcenia ogólnego dla czteroletniego liceum ogólnokształcącego, pięcioletniego technikum oraz dwuletniej branżowej szkoły II stopnia. Nowa podstawa programowa dla szkół ponadpodstawowych obowiązuje od roku szkolnego 2019/2020. Zgodnie z wytycznymi, celem przedmiotu jest przygotowanie teoretyczne i praktyczne uczniów do prawidłowego zachowania i właściwych reakcji w sytuacjach kryzysowych, które mogą stanowić zagrożenie dla zdrowia i życia człowieka. Podkreślono, że niezwykle istotna jest praktyczna forma kształcenia, wyrabianie umiejętności, które z czasem powinny stać się nawykiem. Pozwoli to na wykorzystywanie zdobytych kompetencji w warunkach zagrożenia nawet pod wpływem stresu (Podstawa programowa kształcenia ogólnego z komentarzem, szkoła ponadpodstawowa: liceum ogólnokszałcące, technikum oraz branżowa szkoła I stopnia Edukacja dla bezpieczeństwa, Ministerstwo Edukacji Narodowej).

Jak wskazuje prof. dr hab. n. med. Grzegorz Raczak, przewodniczący zespołu nowej podstawy programowej, główne kryteria brane pod uwagę dotyczyły między innymi zmiany proporcji między teorią a praktyką na korzyść tej drugiej. Pozostałe rekomendacje obejmowały: prowadzenie ćwiczeń praktycznych zgodnie ze standardami renomowanych towarzystw naukowych, realizację samodzielnie opracowanego planu postępowania, poznanie istoty bezpieczeństwa państwa, przygotowanie do działań w sytuacjach nadzwyczajnych zagrożeń (katastrof i wypadków masowych), 
kształtowanie umiejętności z zakresu podstaw pierwszej pomocy, kształtowanie umiejętności indywidualnych i społecznych sprzyjających zdrowiu.

Edukacja dzieci i młodzieży w szkołach spełnia swoistą rolę w kształtowaniu bezpiecznych zachowań i postaw. Na świecie istnieją tendencje, aby naukę bezpieczeństwa wprowadzać bardzo wcześnie do procesu wychowania i edukacji społecznej. W Polsce wprowadzono tę tematykę już na etapie edukacji przedszkolnej, w ramach której przekazywane są informacje o zagrożeniach, z którymi zetknąć się mogą dzieci na co dzień. Jednak, aby efekty tej edukacji przynosiły wymierne rezultaty potrzebny jest system, który wprowadzałby nie tylko wcześniej tę tematykę do procesu edukacji, ale również zakładałby kontynuację w ciągu całego okresu edukacji oraz obejmował osoby dorosłe, znajdujące się już poza procesem oświaty (Kwiasowki, 2004, s. 33-38, Stajszczak, s. 87-88). Warto w tym miejscu nawiązać do tego, jak edukacja na rzecz bezpieczeństwa traktowana jest w Szwecji, która uważana jest za jedno z najbezpieczniejszych państw w Europie. Bezpieczeństwo, edukację dla bezpieczeństwa traktuje się wyjątkowo priorytetowo. Bardzo wcześnie wprowadza się edukację dla bezpieczeństwa do procesu dydaktycznego. Liga Obrony Cywilnej Szwecji (Civilförsvarsförbundet) organizuje szkolenia z zakresu ryzyka, promuje bezpieczne zachowania i postawy, prowadzi szkolenia dla ludności dotyczące zapobiegania, przygotowania i reagowania na zagrożenia, prowadzi naukę pierwszej pomocy, reagowania w sytuacjach kryzysowych. Zajmuje się organizacją programów edukacyjnych dla dzieci, rodziców i opiekunów. Szkolenia są przeznaczone już nawet dla dzieci od czwartego roku życia. Dotyczą rozpoznawania i zapobiegania wypadkom w środowisku lokalnym. Dzieci uczą się elementów pierwszej pomocy, co należy robić w sytuacji, gdy dojdzie np. do poparzenia. Najmłodsi są również edukowani w zakresie podstaw bezpiecznego zachowania się podczas życia codziennego, czy wzywania służb ratunkowych (Trocha, 2017, s. 28-30).

Ważnym argumentem $\mathrm{w}$ realizacji zagadnień związanych $\mathrm{z}$ edukacją dla bezpieczeństwa w instytucjach oświatowych jest odpowiednie przygotowanie kadry dydaktycznej. Jak wskazuje podstawa programowa przedmiotu edukacja dla bezpieczeństwa, zakres tematyczny jest bardzo szeroki, nie wszystkie zagadnienia można realizować w formie ćwiczeń. Dlatego warunkiem odpowiedniego przygotowania społeczeństwa w aspekcie prawidłowego działania w sytuacjach zagrożenia jest kompleksowe podejście w budowaniu 
modelowego systemu edukacji dla bezpieczeństwa nie tylko w Polsce, ale na całym świecie. Wykorzystanie możliwości współpracy w podmiotami zewnętrznymi może zapewnić trwałość i stabilność takiego sytemu.

\section{Organizacje pozarządowe w edukacji na rzecz bezpieczeństwa}

Organizacją pozarządową określa się jako dobrowolne zrzeszenie obywateli, działające zgodnie z przyjętymi regułami i zasadami w celu osiągnięcia określonego celu. Ich charakterystyczną cechą jest to, iż nie funkcjonują w ramach struktury rządowej. Tworzą one tzw. trzeci sektor i są fundamentem społeczeństwa obywatelskiego (Kitler, Skrabacz, 2010, s. 209).

Organizacje pozarządowe, które mają znaczny wkład w kształtowanie świadomości społeczeństwa w zakresie bezpieczeństwa i przyczyniają się do wzrostu umiejętności w obszarze bezpiecznych zachowań i postaw sklasyfikować możemy do następujących grup:

1. Ochotnicze straże pożarne (zrzeszone w Związku Ochotniczych Straży Pożarnych RP).

2. Społeczne organizacje ratownicze (odnosząc się do kryterium w ustawie z dnia 8 września 2006 r. o Państwowym Ratownictwie Medycznym (Dz.U. 2006 nr 191 poz. 1410, z późn. zm.) występuje określenie jednostek mogących współpracować z PRM jako społeczne organizacje ratownicze, które $\mathrm{w}$ ramach swoich zadań ustawowych są zobowiązane do niesienia pomocy w sytuacji zagrożenia zdrowia lub życia). Wymienić tu należy m.in. Wodne Ochotnicze Pogotowie Ratunkowe, Tatrzańskie Ochotnicze Pogotowie Ratunkowe, Polski Czerwony Krzyż.

3. Organizacje o profilu edukacyjno-wychowawczym skierowane przede wszystkim do młodzieży i dzieci, np. Związek Harcerstwa Polskiego, czy Związek Harcerstwa Rzeczypospolitej (Drabik, 2015, s. 149-162).

Działalność prowadzona przez organizacje pozarządowe należy uznać za wysoce specjalistyczną, która stanowi ważny filar w uzupełnieniu kształcenia w szkołach. Przeprowadzone przez autorkę wywiady w 2021 roku wśród 540 nauczycieli przedmiotu edukacja dla bezpieczeństwa wskazują, że znaczna grupa współpracuje ze służbami mundurowymi oraz organizacjami pozarządowymi, które specjalizują się w propagowaniu bezpieczeństwa i posiadają 
przygotowaną ofertę edukacyjną. Wśród nich głównie wymieniana była Państwowa Straż Pożarna, Policja, Straż Miejska, Górskie Ochotnicze Pogotowie Ratunkowe, Tatrzańskie Pogotowie Ratunkowe oraz Polski Czerwony Krzyż.

Tematyka, która realizowana jest przez organizacje pozarządowe dotyczy zagadnień związanych z zagrożeniami, które występują we współczesnym świecie. Polski Czerwony Krzyż posiada 19 Grup Ratownictwa, które nie tylko ratują ludzi w nagłych wypadkach, ale na stałe współpracują z nauczycielami, oswajają temat dbania o szeroko rozumiane bezpieczeństwo prowadząc edukację dla dzieci w przedszkolach i szkołach. Podmiot ten prowadzi również kampanię edukacyjną pod hasłem „Bądź bezpieczny z PCK”, w ramach której uczy, w jaki sposób przygotować się na kryzysowe sytuacje, wypadki i katastrofy (pck.pl/edukacja/).

Aktywności realizowane przez międzynarodowe oddziały Czerwonego Krzyża są szczególnie cenione przez społeczności. Międzynarodowa Federacja Stowarzyszeń Czerwonego Krzyża i Czerwonego Półksiężyca (The International Federation of Red Cross and Red Crescent Societies - IFRC) to największa na świecie organizacja humanitarna. Zrzesza 13,7 miliona wolontariuszy, a efektem ich pracy są programy, wydarzenia, publikacje odnoszące się do kształtowania świadomości i edukacji społecznej w zakresie bezpieczeństwa. Działania te polegają również na pokazywaniu innym, w jaki sposób skutecznie prowadzić działalność edukacyjną, jak projektować działania związane $\mathrm{z}$ nauczaniem wytypowanych grup społecznych w zakresie przeciwdziałania klęskom żywiołowym i katastrofom (Public awareness and public education for disaster..., 2011).

W Stanach Zjednoczonych istnieje wiele organizacji, które na stałe współpracują ze szkołami i z rodzicami. Przykładem mogą być organizacje Family Online Safety Institute (FOSI) Safety Institute (FOSI), the Internet Keep Safe Coalition (IKeepSafe), Drug Abuse Resistance Education (DARE) officers and Enough Is Enough, które zajmują się bezpieczeństwem w cyberprzestrzeni (Government Technology, Cybersecurity Resilience).

Działalność Ochotniczych Straży Pożarnych w Polsce obejmuje wiele aspektów, podstawowe zadania to walka z klęskami żywiołowymi, pomoc ludności w zakresie miejscowych zagrożeń, czy ratownictwo techniczne, działania ratownicze podczas wystąpienia powodzi oraz działania edukacyjne. 
Przykładem aktywności edukacyjnej Ochotniczej Straży Pożarnej jest Szkoła Małego Strażaka. Jest to inicjatywa społeczna OSP w Koble wsparta zaangażowaniem osób Fundacji Czasoprzestrzeń. To próba przekazania wiedzy i umiejętności z zakresu bezpieczeństwa przeciwpożarowego. Inicjatywa obejmuje program edukacyjny do realizacji w szkołach i społecznościach lokalnych (Bubak, 2018, s. 80; OSP Koblo).

Grupa podhalańska Górskiego Ochotniczego Pogotowia Ratunkowego od wielu lat prowadzi programy i szkolenia profilaktyczne dla osób dorosłych, młodzieży oraz dzieci. Oprócz najbardziej popularnego programu „W górach Bezpiecznie" zajęcia prowadzone są również w innych formach programowych w zależności od wieku, doświadczenia i liczebności grupy. Możliwe jest także indywidualne dobranie tematyki i lokalizacji zajęć.

Związek Harcerstwa Polskiego przygotował poradnik Bezpieczeństwo $w Z H P$, dedykowany organizatorom wypoczynku, wychowawcom, instruktorom i wszystkim innym osobom, które uczestniczą w przygotowaniach i realizacji zadań związanych z organizacją harcerskiej akcji letniej i zimowej, wskazówek dotyczących bezpiecznego zorganizowania pracy i zajęć. Przedstawione $\mathrm{w}$ poradniku materiały zostały zebrane $\mathrm{z}$ wielu źródeł - zarówno z poradników dedykowanych przez ministerstwa, jak i ustaw i rozporządzeń, opracowań dotyczących wypoczynku, a także na podstawie doświadczeń członków Zespołu ds. bezpieczeństwa w ZHP. Uwzględnia on wiele zagrożeń od codziennych wypadków, bezpiecznego transportu, zabezpieczenia medycznego, poprzez omówienie gwałtownych zjawisk atmosferycznych (bardzo silny wiatr, trąba powietrzna, nawalny deszcz), kończąc na zagrożeniach pożarowych i energetycznych.

Należy podkreślić, że aktywność poszczególnych organizacji pozarządowych, realizowana na polu edukacji dla bezpieczeństwa jest niezbędna zwłaszcza w odniesieniu do zdobywania kompetencji przez uczniów w ramach specjalistycznej współpracy eksperckiej. Dla globalnego postrzegania i kształtowania systemu edukacji dla bezpieczeństwa konieczna jest współpraca na płaszczyźnie instytucji oświatowych i organizacji pozarządowych. Organizacje te stanowią nieocenione wsparcie w zakresie edukacji nieformalnej w bezpieczeństwie. Jest to specjalistyczna pomoc w obszarach, w których jednostki rządowe, samorządowe czy oświatowe, nie są w stanie w pełni zapewnić pomocy. 


\section{Służby mundurowe a prewencja społeczna, profilaktyka i edukacja w bezpieczeństwie}

Podobnie jak organizacje pozarządowe, służby mundurowe pełnią ważną rolę $\mathrm{w}$ ramach profilaktyki w zakresie bezpieczeństwa. W związku z koniecznością przeciwdziałania katastrofom i klęskom żywiołowym powstała koncepcja stworzenia prewencji społecznej, która określana jest jako zapobieganie zjawiskom niekorzystnym, zagrożeniom i usuwanie ich przyczyn. Tak opisywane zadania prewencji społecznej realizowane są przez instytucje państwowe i służby mundurowe, a należą do nich m.in. straż pożarna, policja, straż miejska, czy inspekcje pracy. Zarówno Państwowa Straż Pożarna, policja czy straż miejska wykonują swoje zadania edukacyjne w obszarze bezpieczeństwa, głównie ze względu na możliwość wykorzystywania bogatej bazy eksperckiej, dydaktycznej i logistycznej. Przygotowywane są kompleksowe programy poprawy bezpieczeństwa, które swoim odbiorcom oferują nie tylko podniesienie kompetencji w zakresie reagowania na zdarzenia niepożądane, ale również wyposażają $\mathrm{w}$ umiejętności przewidywania i unikania sytuacji mogących stanowić zagrożenie życia i zdrowia człowieka.

Działania profilaktyczne realizowane przez Państwową Straż Pożarną obejmują spektrum tematów, które realizowane są na wielu płaszczyznach; w formie zajęć lekcyjnych (w specjalnie wyposażanych w całej Polsce salach edukacyjnych Ognik), programów profilaktycznych i kampanii społecznych (Bezpieczne życie, Bezpieczna woda, Kręci mnie bezpieczeństwo i inne). Tematyka, która jest najczęściej poruszana to bezpieczeństwo pożarowe, bezpieczeństwo nad wodą, bezpieczeństwo w domu, w przedszkolu, pierwsza pomoc, ochrona zdrowia itd. Są one pokrewne z treściami programowymi realizowanymi w placówkach oświatowych, dlatego płaszczyzna i zasięg współpracy jest bardzo duży.

Obszar prewencji społecznej, który realizowany jest przez funkcjonariuszy policji nieznacznie odbiega od tematyki PSP, jednak specyfika niektórych zagadnień się wyróżnia. Najważniejsze tematy to: bezpieczeństwo ruchu drogowego, bezpieczeństwo w sieci, edukacja antyterrorystyczna, bezpieczeństwo dzieci, młodzieży, seniorów. Przedsięwzięciem o dużym zasięgu był program Razem bezpieczniej, którego celem była nie tylko poprawa świadomości na temat przeciwdziałania zagrożeniom, takim jak: bezpieczeństwo 
w ruchu drogowym, w działalności gospodarczej, czy ochrona dziedzictwa narodowego. Ważnym aspektem jest bank dobrych praktyk oraz udostępnienie materiałów dydaktycznych dla nauczycieli. Podobne działania na rzecz edukacji dla bezpieczeństwa podejmuje Straż Graniczna, Straż Miejska czy Służba Więzienna.

Z roku na rok zauważyć można coraz większą liczbę programów prewencji społecznej realizowanych przez służby mundurowe. Wiąże się to z podniesieniem rangi fazy przygotowania i zapobiegania zarządzania kryzysowego, które pełnią kluczową rolę w przygotowaniu społeczeństwa do unikania, przeciwdziałania i radzenia sobie ze zdarzeniami niepożądanymi.

\section{Wnioski}

Nowocześnie pojmowana edukacja to taka, w której nauczyciel ma prawo do elastycznego podejścia do przedmiotu. Obecnie nauczyciele mają duży wpływ na realizację programu nauczania oraz możliwość dostosowywania treści programowych do aktualnych potrzeb i występujących zagrożeń. Dotyczy to również podejmowania współpracy z podmiotami zewnętrznymi, szczególnie z organizacjami pozarządowymi oraz służbami mundurowymi, które oferują specjalistyczną wiedzę w obszarze bezpieczeństwa. Ma to szczególne znaczenie w odniesieniu do interdyscyplinarnego charakteru edukacji dla bezpieczeństwa, gdyż wieloaspektowość tematu ogranicza możliwość wyspecjalizowania się nauczycieli w aż tak szerokim zakresie.

Rola nauczyciela w obszarze przekazywania wiedzy i umiejętności w zakresie bezpieczeństwa powinna opierać się m.in. na koordynowaniu współpracy eksperckiej z podmiotami zewnętrznymi, np. poprzez uczestnictwo w projektach naukowych, edukacyjnych, programach i kampaniach społecznych. Współczesna edukacja musi łączyć obszar edukacji formalnej i nieformalnej, aby móc łączyć cechy edukacji globalnej i światowej. Dzięki niej dostęp do najnowocześniejszych metod i form kształcenia pozostaje otwarty.

Współpraca z podmiotami zewnętrznymi i łączenie edukacji formalnej i nieformalnej pozwala na budowanie najbardziej nowoczesnej formy edukacji. 


\section{Edukacja tradycyjna i edukacja nowoczesna}

Tab. 1. Różnice między edukacją tradycyjną i nowoczesną.

\begin{tabular}{|l|l|}
\hline Edukacja tradycyjna & Edukacja nowoczesna \\
\hline skoncentrowana na nauczycielu & wiedza przedmiotowa oparta na \\
transfer wiedzy w jedną stronę & umiejętnościach \\
pasywna i ograniczona & wielostronny transfer wiedzy \\
głównie teoretyczna & interaktywna i wciągająca \\
koncepcyjna i praktyczna & wysoce specjalistyczna \\
\hline
\end{tabular}

Źródło: opracowanie własne na podstawie Leverage Edu (https://leverageedu.com).

Faktem jest, iż nauka o bezpieczeństwie powinna odbywać się w jak najbardziej praktycznej formie. Uczeń/student - powinien umieć samodzielnie zdobywać wiedzę, a nauczyciel występować w roli mentora. Nauka o bezpieczeństwie powinna mieć bardziej praktyczny i fakultatywny wymiar, aby przede wszystkim kreować umiejętności, nawyki i rozsądek w postrzeganiu bezpiecznych zachowań i postaw. Jak wskazują wieloletnie obserwacje praktycznych aspektów tworzenia edukacji dla bezpieczeństwa w Polsce istnieje wiele inicjatyw, których intencją jest podnoszenie świadomości społeczeństwa w zakresie bezpieczeństwa. Jednak najczęściej są to działania lokalne, nie będące częścią kompleksowego systemu edukacji dla bezpieczeństwa.

Warunkiem powstania efektywnego systemu edukacji na rzecz bezpieczeństwa jest uwzględnienie następujących kryteriów:

1. Systemowe i kompleksowe działania - podejmowane aktywności muszą być usystematyzowane, cykliczne i odpowiednio wcześniej zaplanowane z uwzględnieniem współczesnych zagrożeń. Jednorazowe akcje podejmowane tylko w społecznościach lokalnych są bardzo cenne, ale ich efektywność w długofalowym działaniu jest niska.

2. Współpraca instytucji rządowych, samorządowych, organizacji pozarządowych, placówek oświatowych, służb - zgodnie z celem postawionym w niniejszym opracowaniu. Ważne jest wypracowanie form działania, które pozwolą na wykorzystanie bazy eksperckiej i możliwości specjalistycznych instytucji i organizacji, które nie tylko posiadają fachową wiedzę, ale również nowoczesne zaplecze 
edukacyjne (np. Centrum Edukacji Przeciwpożarowej w Chorzowie-najnowocześniejsza w Polsce sala edukacyjna w zakresie bezpieczeństwa przeciwpożarowego, dedykowana dla dzieci i młodzieży).

3. Dotarcie do wszystkich grup docelowych - edukacja na rzecz bezpieczeństwa dotyczyć powinna całego społeczeństwa. Proces ten obejmuje zarówno dzieci, młodzież, jak i osoby dorosłe. Oczywiście edukacja dorosłych należy do najtrudniejszych. W zorganizowanej formie można ją prowadzić jedynie w postaci dobrowolnych kursów i szkoleń. Wiele krajów na świecie wykorzystuje w edukacji dorosłych oddziaływanie dzieci na swoich rodziców. Współpraca poszczególnych grup społecznych lub zawodowych przyczynia się do integracji środowiska lokalnego. Integracja, tworzenie więzi środowiskowych i międzypokoleniowych zwiększa poczucie odpowiedzialności za stan środowiska lokalnego, a w sytuacjach zagrożenia - poczucie bezpieczeństwa mieszkańców (Zaczek-Zaczyński, 2006, s. 10-12).

4. Wykorzystanie wszystkich form edukacji - obecnie wyróżnić możemy wiele form edukacji, formalną, nieformalną, incydentalną i autoedukacją. Każda z nich spełnia w procesie uczenia się człowieka inną rolę. Integracja wszystkich form edukacji pozwoli na wykorzystanie całego dostępnego potencjału wiedzy eksperckiej. Daje to szansę na kreowanie podstaw nowoczesnej edukacji.

5. Doświadczenie wszystkich krajów - współpraca międzynarodowa. Wypracowanie wspólnego pola doświadczeń jest ogromnie ważne. Istotną rolę ogrywają tu wspólne projekty i programy o szerokim zasięgu terytorialnym. Przykładem trwającej współpracy zagranicznej w ramach edukacji dla bezpieczeństwa jest zapoczątkowany kilka lat temu w Skovde (Szwecja) program „Bezpieczne gminy”, który został zaimplementowany w polskich warunkach i realiach (w Tarnowskich Górach) i przyniósł duże efekty, jeśli chodzi o poprawę bezpieczeństwa mieszkańców.

Wysoki poziom edukacji oraz współpraca z wyspecjalizowaną kadrą naukowo-dydaktyczną stanowi element wzmacniający system bezpieczeństwa państwa. Warunkiem odpowiedniej realizacji zagadnień związanych z edukacją dla bezpieczeństwa jest właściwe zrozumienie jej istoty i złożoności, a co za tym idzie, związków z poszczególnymi dyscyplinami nauki, czyli jej 
interdyscyplinarności. Z praktycznego punktu widzenia oznacza wypracowanie stałych zasad współpracy w ramach realizacji edukacji formalnej i pozaformalnej w kształtowaniu świadomości społeczeństwa w zakresie bezpieczeństwa.

BRYG. DR IZABELLA GRABOWSKA-LEPCZAK

Szkoła Główna Służby Pożarniczej

ul. Słowackiego 52/54, 01-629 Warszawa

igrabowska@sgsp.edu.pl

\section{Bibliografia}

Bubak, M. (2018). Rola Ochotniczych Straży Pożarnych w budowaniu bezpieczeństwa lokalnego. Studia de Securitate 8. DOI 10.24917/20820917.8. Pobrane z: https:// osp.pl/artykuly/szkola-malego-strazaka-innowacyjny-program-edukacyjny-osp-koblo, 18798/.

Drabik, I. (2015). Rola i znaczenie organizacji pozarządowych w zarządzaniu kryzysowym. Zeszyty Naukowe Politechniki Częstochowskiej, Zarządzanie Nr 20, s. 149-162. Pobrane z: http://www.zim.pcz.pl/znwz.

Elak, H. (2017). Edukacja na rzecz bezpieczeństwa w świetle nowej reformy oświaty. Obronność Zeszyty Naukowe 3(23), s. 17-41.

Government Technology, Cybersecurity Resilience. Pobrane z: https://www.govtech. $\mathrm{com} /$ security/nonprofit-organizations-collaborate-to.html.

Harlen, W. (red.). (2010). Principles and big ideas of science education. The Association for Science Education, s. 2-7.

Https://pck.pl/edukacja/.

Lesiński, L.S. (2019). Bezpieczny uczeń, Program nauczania przedmiotu edukacja dla bezpieczeństwa, III etap edukacyjny - zakres podstawowy, opracowany w ramach projektu „Tworzenie programów nauczania oraz scenariuszy lekcji i zajęć wchodzących w skład zestawów narzędzi edukacyjnych wspierających proces kształcenia ogólnego w zakresie kompetencji kluczowych uczniów niezbędnych do poruszania się na rynku pracy" dofinansowanego ze środków Funduszy Europejskich w ramach Programu Operacyjnego Wiedza Edukacja Rozwój, 2.10 Wysoka jakość systemu oświaty. Ośrodek Rozwoju Edukacji.

Kitler, W., Skrabacz, A. (2010). Bezpieczeństwo ludności cywilnej. Pojęcie, organizacja i zadania w czasie pokoju, kryzysu $i$ wojny. Towarzystwo Wiedzy Obronnej.

Kopaliński, W. (1999). Słownik wyrazów obcych i zwrotów obcojęzycznych. Oficyna Wydawnicza. 
Kwiasowski, Z. (2004). Bezpieczeństwo w kształceniu nauczycieli. W: M. Ożóg-Radew, R. Rosa (red.). Bezpieczeństwo i prawa człowieka, Edukacja do bezpieczeństwa i praw człowieka, Tom II, Wydawnictwo Akademii Podlaskiej.

Kwieciński, Z. (1991). Edukacja jako wartość odzyskiwana wspólnie (Głos w dyskusji o uspołecznieniu szkoły). Edukacja, 1, s. 89.

Leverage Edu. Pobrane z: https://leverageedu.com.

Niemierko, B. (2009). Cele kształcenia. W: K. Kruszewski (red.). Sztuka nauczania. Czynności nauczyciela, Wydawnictwo Naukowe PWN.

Patriotyzm, obronność, bezpieczeństwo. (1998). W: R. Stępień (red.). System edukacji obronnej społeczeństwa RP. Akademia Obrony Narodowej.

Pełech, B. Edukacja formalna, pozaformalna i nieformalna $w$ nauczaniu. Zachodniopomorskie Centrum Doskonalenia Nauczycieli, Szczecin. Pobrane z: cdn.edu.pl/ wp-content/uploads/2018/03/edukacja-formalna-pozaformalna-i-nieformalna-w-nauczaniu.pdf.

Pieczywok, A. (2012). Edukacja dla bezpieczeństwa wobec zagrożeń i wyzwań współczesności. Akademia Obrony Narodowej.

Pieczywok, A. (2011). Wybrane problemy z zakresu edukacji dla bezpieczeństwa. Akademia Obrony Narodowej.

Podstawa programowa kształcenia ogólnego, z komentarzem, z komentarzem, Szkoła ponadpodstawowa: liceum ogólnokształcąe, technikum oraz branżowa szkoła I stopnia Edukacja dla bezpieczeństwa. Ministerstwo Edukacji Narodowej. Pobrane z: www. ore.edu.pl.

Public awareness and public education for disaster risk reduction: a guide. (2011). International Federation of Red Cross and Red Crescent Societies. Geneva.

Stajszczak, M. (2004). Edukacja dla bezpieczeństwa - inwestycją w przyszłość. W: M. Ożóg-Radew, R. Rosa (red.). Bezpieczeństwo i prawa człowieka, Edukacja do bezpieczeństwa i praw człowieka, Tom II. Wydawnictwo Akademii Podlaskiej, s. 87-88.

Trocha, J. (2017). Ochrona ludności w Szwecji jako przykład nowoczesnych rozwiązań w dziedzinie bezpieczeństwa cywilnego. Zeszyty Naukowe Zbliżenia Cywilizacyjne, XIII(1). DOI: http://dx.doi.org/10.21784/ZC.2017.002.

Ustawa z dnia 8 września 2006 r. o Państwowym Ratownictwie Medycznym (Dz.U. 2006 nr 191 poz. 1410, z późn. zm.), art. 15 ust. 2.

Włodarczyk, E., Sadowska-Wieciech, E., Rokitowska, J. (2018). Edukacja dla bezpieczeństwa Istota i uwarunkowania. Instytut Nauk o Bezpieczeństwie, Uniwersytet Pedagogiczny im. Komisji Edukacji Narodowej.

Zaczek-Zaczyński, K.M. (2006). O skuteczności wdrażania i zarządzania szkolną edukacją dla bezpieczeństwa. Edukacja dla bezpieczeństwa, 3(29), s. 10-12.

Zaki, C. (1998). Formal, non-formal and informal education: concepts/applicability. Presented at the "Interamerican Conference on Physics Education", Oaxtepec, Mexico, 1987. Published in "Cooperative Networks in Physics Education - Conference Proceedings 173", American Institute of Physics, New York, 1988 Dib Institute of Physics University of São Paulo. 